\title{
Changes in soil chemical and physical properties in pasture fertilised with liquid swine
}

\section{manure}

\author{
Douglas Leandro Scheid ${ }^{*} \oplus$, Rodrigo Ferreira da Silva ${ }^{2} \odot$, Vanderlei Rodrigues da Silva ${ }^{2} \odot$, Clovis Orlando Da Ros ${ }^{2}$, Marlo Adriano \\ Bison Pinto ${ }^{3}$, Márcia Gabriel ${ }^{3 \oplus}$, Maurício Roberto Cherubin ${ }^{4} \odot$
}

\begin{abstract}
1Universidade Federal de Santa Maria - Depto. de Solos, Av. Roraima, 1000 - 97105-900 - Santa Maria, RS - Brasil. ¿Universidade Federal de Santa Maria - Depto. de Ciências Agronômicas e Ambientais, Linha Sete de Setembro, BR 386 km 40 - 98400-000 - Frederico Westphalen, RS - Brasil. 3Universidade Federal de Santa Maria - Depto. de Fitotecnia, Av. Roraima, 1000 - 97105-900 - Santa Maria, RS - Brasil. 4Universidade de São Paulo/ESALQ - Depto. de Ciência do Solo, Av. Pádua Dias, 11 - 13400-970 - Piracicaba, SP Brasil.

*Corresponding author <douglasscheid@gmail.com>
\end{abstract}

Edited by: Francesco Montemurro

Received January 25, 2019

Accepted April 24, 2019

\section{Introduction}

The production of pork meat is concentrated in family farms in southern Brazil, and plays a fundamental role in the socio-economic development of the region. However, the environmental impacts associated with large amounts of manure produced by intensive swine production in small farms have caused intense debates, threatening the sustainability of this productive chain. In Brazil, 43 million animals are slaughtered annually (FAO, 2019), producing 300 million liters of liquid swine manure (LSM) daily (Oliveira et al., 2017). Therefore, to define an environmentally correct fate for LSM is one of the major challenges faced in the last decades by swine producers and stakeholders.

Historically, LSM has been used as organic fertilizer, mainly as a source of $\mathrm{N}$ (Woli et al., 2013), in areas cultivated with pastures and annual crops (Freitas et al., 2018; Guardini et al., 2012; Oliveira et al., 2017). Successive applications of LSM, as organic fertilizer, enhance the growth and accumulation of dry matter biomass of Cynodon sp. cv. Tifton 85 (Ames et al., 2014), which is well-adapted to the subtropical climate conditions of southern Brazil, and is characterized by rapid growth and high digestibility (Burton, 2001).

Nutrient recycling from the application of LSM in the soil is important to increasing the sustainability of the production system (Guardini et al., 2012). Several studies have revealed that successive applications of LSM can increase soil $\mathrm{P}, \mathrm{K}, \mathrm{Mg}, \mathrm{Ca}, \mathrm{Cu}, \mathrm{Mn}$ and $\mathrm{Zn}$ con- tents, mainly in the surface layers, i.e., $0-10 \mathrm{~cm}$ (Formentini et al., 2015; Lourenzi et al., 2015; Grohskopf et al., 2016a; Boitt et al., 2018), and influence the attributes of soil acidity (Lourenzi et al., 2015). Long-term use of LSM may increase soil C (Oliveira et al., 2017), with positive implications for chemical and physical properties of the soil (Cherubin et al., 2016). In the short term, LSM promotes few or even no changes in soil physical attributes, i.e. soil bulk density, macroporosity, total porosity (Freitas et al., 2018; Cherubin et al., 2015). However, the increasing $\mathrm{C}$ probably does have positive implications for physical quality (Johannes et al., 2017), which may result in increased soil resilience and resistance to compaction (Bonetti et al., 2017), the main cause of pasture degradation (Drewry et al., 2008).

Based on this, the hypothesis was that long-term use of LSM improves not only the soil chemical attributes, but also the soil physical attributes, offering a strategy for the sustaining of soil quality in cultivated pastures. Thus, a field study was conducted to evaluate changes in the chemical and physical attributes of soil in Cynodon pasture areas under successive LSM application for different lengths of time.

\section{Materials and Methods}

\section{Description of the study field}

The study areas are located in Nova Candelária,

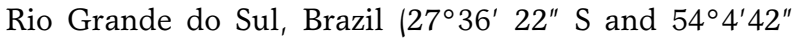
W) (Figure 1A), approximately $226 \mathrm{~m}$ above sea level. 
The regional climate is subtropical humid with hot summers, Cfa type (Köppen climate classification) (Alvares et al., 2014), presenting an average annual temperature of $18{ }^{\circ} \mathrm{C}$ and average annual precipitation of $1,800 \mathrm{~mm}$. The soil in the area was characterized as a Hapludox (Soil Survey Staff, 2014), with $510 \mathrm{~g} \mathrm{~kg}^{-1}$ of clay. The mineralogy of the clay-size fraction is composed mainly of clay minerals (i.e., kaolinite) and iron and aluminum oxides (Schaefer et al., 2008) in a ratio of 1:1.

The study was conducted on three adjacent areas cultivated with cv. Tifton 85 (Cynodon spp.) for animal grazing, which were subjected to annual applications of LSM for three, eight and 15 years, respectively, (Figure 1B) plus an undisturbed native forest area which was sampled as a reference. The LSM-amended areas presented a slope of $3 \%$, and there were terraces to prevent runoff and potential loss of soil and manure. Historically, before the pasture was planted, the areas had been cultivated with annual crops, such as corn, sorghum and soybean in the summers, and oats and ryegrass for grazing in the winters. The pasture was planted including soil tillage down to a depth of $30 \mathrm{~cm}$ followed by light harrowing. The next stage was for these areas to receive broadcast application of approximately $200 \mathrm{~m}^{3} \mathrm{ha}^{-1} \mathrm{yr}^{-1}$ of LSM. Although there were no records of the exact composition of the LSM applied over the years, the amount of nutrients and organic $\mathrm{C}$ added in the areas was estimated based on available data in the literature (Table 1).

\section{Soil sampling}

In each of the areas studied (i.e., three, eight and 15 years of LSM use and native forest), six sample points were randomly demarcated. At each point, both disturbed and undisturbed samples were collected for chemical and physical analysis, respectively. Soil sam- ples were taken from the soil in Oct 2014, and the samples with preserved structure were collected using metal cylinders $(5 \mathrm{~cm}$ high $\times 4.8 \mathrm{~cm}$ diameter $)$, from layers $2-7 ; 10-15 ; 15-20$ and $20-25 \mathrm{~cm}$. Disturbed samples were collected from layers $0-5 ; 5-10 ; 10-15 ; 15-20$ and 20-25 $\mathrm{cm}$, each sample being composed of three subsamples. Both disturbed and undisturbed samples were stored in identified plastic bags and transported to the soil chemical and physical laboratory for preparation and analysis.

\section{Soil chemical and physical attributes}

Disturbed samples were oven dried at $40{ }^{\circ} \mathrm{C}$ for 72 $\mathrm{h}$ and then sieved and the $2 \mathrm{~mm}$ mesh portion collected. Organic $\mathrm{C}$ was determined according to the methodology employed by Yeomans and Bremner (1988), in which $0.5 \mathrm{~g}$ of soil was digested with $5 \mathrm{~mL}$ of potassium dichromate solution $(1 \mathrm{~N})$ plus $7.5 \mathrm{~mL}$ of concentrated sulphuric acid $\left(\mathrm{H}_{2} \mathrm{SO}_{4}\right)$ at $170{ }^{\circ} \mathrm{C}$ for $30 \mathrm{~min}$. Afterwards, the solution was titrated with Mohr's salt solution $(0.2 \mathrm{~N})$. The $\mathrm{pH}$ was determined by potentiometry in the soil suspension and water (1:1). Soil available P and $\mathrm{K}$ were extracted by the Mehlich-1 solution $\left(\mathrm{HCl} 0.05 \mathrm{~mol} \mathrm{~L}^{-1}+\right.$ $\left.\mathrm{H}_{2} \mathrm{SO}_{4} 0.0125 \mathrm{~mol} \mathrm{~L}^{-1}\right)$. Briefly, for each sample, $3 \mathrm{~cm}^{-3}$

Table 1 - Estimate of nutrient and organic carbon (OC) inputs via liquid swine manure (LSM) in the Cynodon areas.

\begin{tabular}{|c|c|c|c|c|c|c|c|c|}
\hline \multirow{2}{*}{ Area } & \multicolumn{2}{|c|}{ LSM } & \multicolumn{5}{|c|}{ Nutrients * } & \multirow{2}{*}{$O C^{*}$} \\
\hline & Annual & Total & $\mathrm{N}$ & $P$ & K & $\mathrm{Cu}$ & $\mathrm{Zn}$ & \\
\hline & \multicolumn{2}{|c|}{$\mathrm{m}^{3} \mathrm{ha}^{-1}$} & \multicolumn{6}{|c|}{$\mathrm{kg} \mathrm{ha}^{-1}$} \\
\hline 3 years & 200 & 600 & 1926 & 876 & 900 & 8.16 & 26.82 & 8520 \\
\hline 8 years & 200 & 1600 & 5136 & 2336 & 2400 & 22.4 & 71.52 & 22720 \\
\hline 15 years & 200 & 3000 & 9630 & 4380 & 4500 & 42.0 & 137.1 & 42600 \\
\hline
\end{tabular}

${ }^{*}$ Amounts of nutrients and Organic Carbon $(\mathrm{OC})$ added to soil were estimated based on Broetto et al. (2014), Grohskopf et al. (2016b) and Nicolosso et al. (2016). Amount of nutrient is the total input for three, eight and 15 years.
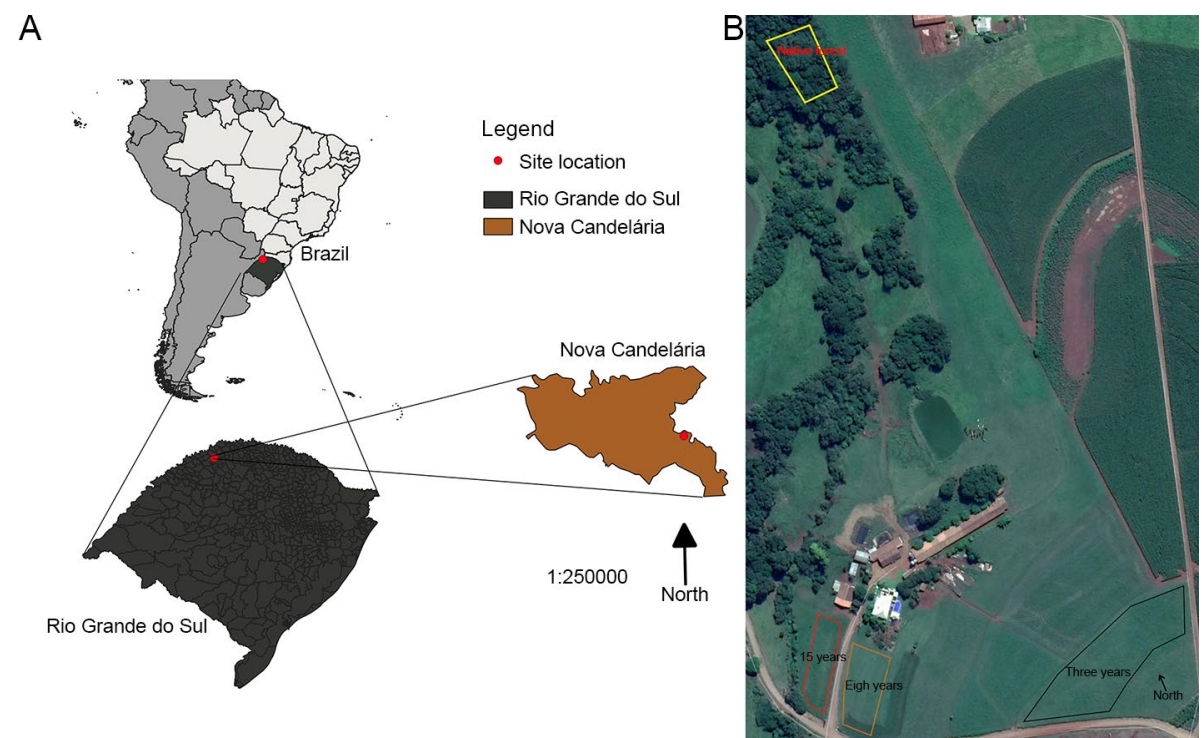

Figure 1 - Location map of experimental site (A) and aerial image of the native forest and areas under three, eight and 15 years of Cynodon spp. cultivation with annual application of liquid swine manure (B). 
of soil was added with $30 \mathrm{~mL}$ of Mehlich-1 solution in a glass snap-cap vial, agitated for $5 \mathrm{~min}$ and left to sediment overnight. Next day, 3 to $6 \mathrm{~mL}$ of supernatant were extracted to quantify available $\mathrm{P}$ and $\mathrm{K}$ by the flame photometry and colorimetry method, respectively. Exchangeable soil $\mathrm{Ca}$ and $\mathrm{Mg}$ were extracted from $2.5 \mathrm{~cm}^{-3}$ of soil by $50 \mathrm{~mL}$ of $\mathrm{KCl}$ solution $\left(1 \mathrm{~mol} \mathrm{~L}^{-1}\right)$. The solution was agitated for $30 \mathrm{~min}$, left to sediment overnight, and then, $5 \mathrm{~mL}$ was extracted to quantify $\mathrm{Ca}$ and $\mathrm{Mg}$ by atomic absorption spectrometry. The available $\mathrm{Cu}$ and $\mathrm{Zn}$ were extracted from $10 \mathrm{~cm}^{-3}$ of soil by $40 \mathrm{~mL}$ of $\mathrm{HCl}$ solution $\left(0.1 \mathrm{~mol} \mathrm{~L}^{-1}\right)$. The solution was agitated for 30 min, left to sediment overnight and then, these elements were quantified by atomic absorption spectrometry. All the chemical analysis methodologies are described in detail in Teixeira et al. (2017).

Undisturbed samples were saturated with water by capillarity in plastic trays, and afterwards equilibrated in the matrix potential of $-6 \mathrm{kPa}$ in a tension table. Soil bulk density $\left(\rho_{b}\right)$ was calculated by dividing the dry soil mass by the cylinder volume. Total porosity (Tp) was determined by calculation, where Tp $=1-\left(\rho_{\mathrm{b}}\right)$ Dp), $\rho_{b}$ is bulk density and Dp soil particle density. The Dp was determined by the volumetric balloon method for each area. The determined $\mathrm{Dp}$ were $2.94 \mathrm{~kg} \mathrm{dm}^{-3}$, $2.90 \mathrm{~kg} \mathrm{dm}^{-3}, 2.75 \mathrm{~kg} \mathrm{dm}^{-3}$ and $2.94 \mathrm{~kg} \mathrm{dm}^{-3}$ for the areas under three, eight and 15 years of LSM applications, and native forest, respectively. Soil macroporosity was determined by the difference between the water content in the saturated sample and the retained water of the sample submitted to the matrix potential $-6 \mathrm{kPa}$, whereas the estimation of microporosity was based on the water content retained in the sample submitted to the matrix potential of $-6 \mathrm{kPa}$. These methodologies are also described in Teixeira et al. (2017).

\section{Statistical analysis}

The data were subjected to analysis of variance (ANOVA) considering the layers evaluated as a variation factor. Where significant (F test $p<0.05)$, the means were compared by Tukey's test $(p<0.05)$ using the $\mathrm{R}$ software program (R Core Team, version 3.3).

\section{Results and Discussion}

\section{Organic $\mathrm{C}$ and attributes of soil acidity}

The successive applications of LSM for 15 years in Cynodon spp. cultivation promoted increases in soil organic $\mathrm{C}$ levels at levels equivalent to those found in native forest (Figure 2A and Table 2). However, this increase was focused on the shallowest $0-5 \mathrm{~cm}$ layer, with no changes observed in the layers of 10-15, 15-20 and 20$25 \mathrm{~cm}$. Increases in organic C induced by the use of LSM has been reported in the literature (Lourenzi et al., 2011; Brunetto et al., 2012; Mafra et al., 2015), especially in studies on pastures (Oliveira et al., 2017). In general, these soil organic C increases in areas under LSM application can be attributed to two aspects: i) direct organic
C inputs by LSM, despite the low solids concentration of this manure (Table 1); ii) indirect contribution through nutrient inputs, especially $\mathrm{N}$ (Table 1), which enhances soil fertility, sustaining higher above- and below ground biomass yields, and consequently increase soil organic $\mathrm{C}$ by the decomposition of roots and crop residues (Brunetto et al., 2012; Oliveira et al., 2017).

Higher increments in soil organic $\mathrm{C}$ in the surface layer can be explained by the surface applications of LSM associated with higher root turnover in the soil depth and absence of soil mobilization in the pasture since planting. However, after 20 years of LSM application, Oliveira et al. (2017) showed that increases in organic C in Cynodon spp. pasture reached a depth of 40 $\mathrm{cm}$. In addition to the application duration, soil texture also affects the vertical movement of organic $C$ in the profile. In sandy soils, high doses of LSM can saturate the surface functional groups of mineral particles (Brunetto et al., 2012), and stimulate the migration of these

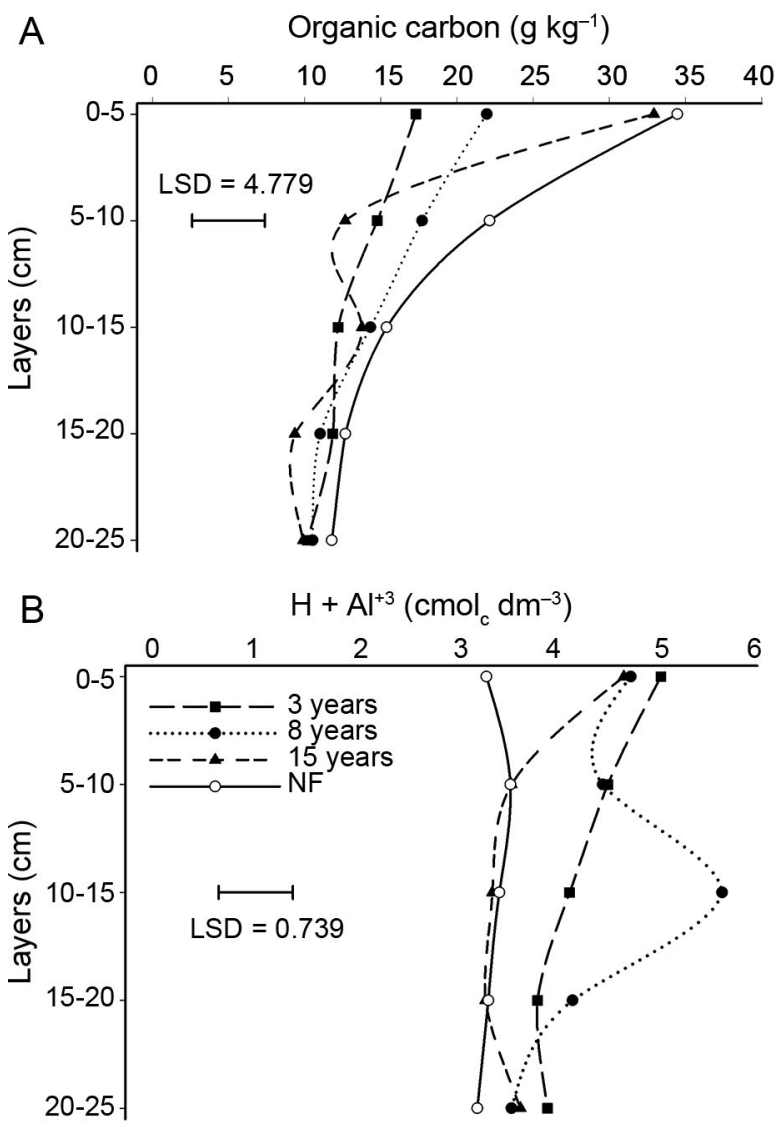

Figure 2 - Soil organic carbon (A) and potential acidity (B) in the native forest (NF) and areas under three, eight and 15 years of Cynodon cultivation with annual application of liquid swine manure. *Horizontal line indicates the least significant difference (LSD) 0 Tukey's test $(p<0.05)$. When the difference between the points is greater than the line there is a significant difference between the treatments. 
Table 2 - Soil available phosphorus, potassium, calcium, magnesium, copper, zinc, organic carbon and potential acidity content in the native forest (NF) and areas under three, eight and 15 years of Cynodon cultivation with annual application of liquid swine manure.

\begin{tabular}{|c|c|c|c|c|c|c|c|c|}
\hline \multirow{2}{*}{ Layer } & 3 years & 8 years & 15 years & NF & 3 years & 8 years & 15 years & $\mathrm{NF}$ \\
\hline & \multicolumn{4}{|c|}{$P$} & \multicolumn{4}{|c|}{$\mathrm{K}$} \\
\hline \multicolumn{9}{|c|}{$\mathrm{mg} d \mathrm{dn}$} \\
\hline $0-5$ & $97.03 \mathrm{Ba}^{*}$ & $81.19 \mathrm{Cc}$ & $259.86 \mathrm{Aa}$ & $6.1 \mathrm{Da}$ & $161.68 \mathrm{Ca}$ & $304.15 \mathrm{Bb}$ & 703.37 Aa & $47.43 \mathrm{Ca}$ \\
\hline $5-10$ & $59.43 \mathrm{Cb}$ & $218.08 \mathrm{Ab}$ & $79.25 \mathrm{Bb}$ & 3.08 Da & $149.39 \mathrm{Ca}$ & $388.4 \mathrm{Bb}$ & $526.39 \mathrm{Ab}$ & $49.86 \mathrm{Ca}$ \\
\hline $10-15$ & $32.28 \mathrm{Cc}$ & $248.19 \mathrm{Aa}$ & $59.78 \mathrm{Bc}$ & 1.84 Da & $144.32 \mathrm{Ca}$ & $376.67 \mathrm{Bb}$ & 566.36 Aab & $45.72 \mathrm{Ca}$ \\
\hline $15-20$ & $12.54 \mathrm{Bd}$ & $42.77 \mathrm{Ad}$ & $33.78 \mathrm{Ad}$ & $1.83 \mathrm{Ba}$ & $185.97 \mathrm{BCa}$ & $592.49 \mathrm{Aa}$ & $258.02 \mathrm{Bc}$ & $58.76 \mathrm{Ca}$ \\
\hline $20-25$ & 4.23 Bd & $21.44 \mathrm{Ae}$ & $29.03 \mathrm{Ad}$ & $2.51 \mathrm{Ba}$ & $128.11 \mathrm{Ba}$ & $343.48 \mathrm{Ab}$ & $162.09 \mathrm{Bc}$ & $43.11 \mathrm{Ba}$ \\
\hline CV (\%) & \multicolumn{4}{|c|}{8.59} & \multicolumn{4}{|c|}{23.63} \\
\hline Layer & \multicolumn{4}{|c|}{$\mathrm{Ca}$} & \multicolumn{4}{|c|}{$\mathrm{Mg}$} \\
\hline $\mathrm{cm}$ & \multicolumn{4}{|c|}{ 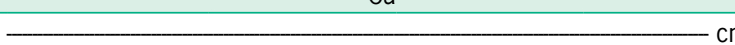 } & & \\
\hline $0-5$ & $6.66 \mathrm{Ca}$ & $6.94 \mathrm{Cab}$ & $10.43 \mathrm{Ba}$ & $12.79 \mathrm{Aa}$ & $3.73 \mathrm{BCa}$ & 3.92 Bab & $4.64 \mathrm{Aa}$ & $3.48 \mathrm{Cab}$ \\
\hline $5-10$ & $6.37 \mathrm{Ba}$ & $6.76 \mathrm{Bb}$ & $9.05 \mathrm{Ab}$ & $9.71 \mathrm{Ab}$ & 3.51 BCab & 3.88 Bab & $4.66 \mathrm{Aa}$ & $3.15 \mathrm{Cbc}$ \\
\hline $10-15$ & $6.02 \mathrm{Ba}$ & $8.08 \mathrm{Aa}$ & $8.30 \mathrm{Abc}$ & $7.87 \mathrm{Ac}$ & 3.37 Cab & $4.04 \mathrm{Ba}$ & $4.44 \mathrm{Aab}$ & $2.94 \mathrm{Dc}$ \\
\hline $15-20$ & $6.45 \mathrm{BCa}$ & $6.23 \mathrm{Cb}$ & $7.53 \mathrm{Abc}$ & 7.71 Bc & 3.38 Bab & $3.56 \mathrm{Bbc}$ & $4.21 \mathrm{Ab}$ & 3.30 Babc \\
\hline $20-25$ & $6.01 \mathrm{C}$ & $6.27 \mathrm{BCb}$ & $7.45 \mathrm{ABC}$ & $8.24 \mathrm{Ac}$ & $3.19 \mathrm{Cb}$ & $3.44 \mathrm{BCc}$ & $4.07 \mathrm{Ab}$ & 3.57 Ba \\
\hline CV (\%) & \multicolumn{4}{|c|}{7.26} & \multicolumn{4}{|c|}{4.57} \\
\hline Layer & \multicolumn{4}{|c|}{$\mathrm{Cu}$} & \multicolumn{4}{|c|}{$\mathrm{Zn}$} \\
\hline $\mathrm{cm}$ & \multicolumn{4}{|c|}{ 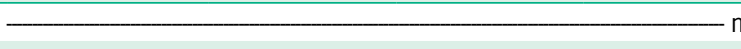 } & \multicolumn{3}{|c|}{ - } & \\
\hline $0-5$ & $41.03 \mathrm{Ba}^{*}$ & $38.71 \mathrm{Bb}$ & $56.54 \mathrm{Aa}$ & $12.56 \mathrm{Cd}$ & $24.27 \mathrm{Ba}$ & $21.91 \mathrm{Bc}$ & $77.74 \mathrm{Aa}$ & $12.22 \mathrm{Ca}$ \\
\hline $5-10$ & $34.47 \mathrm{Bb}$ & $38.74 A b$ & $33.15 \mathrm{Bb}$ & $19.51 \mathrm{Cc}$ & $14.52 \mathrm{Cb}$ & $32.42 \mathrm{Ab}$ & $20.08 \mathrm{Bb}$ & 8.48 Dab \\
\hline $10-15$ & $30.32 \mathrm{Bbc}$ & $49.80 \mathrm{Aa}$ & $32.03 \mathrm{Bb}$ & $25.72 \mathrm{Cb}$ & $9.13 \mathrm{Cc}$ & $61.85 \mathrm{Aa}$ & $17.94 \mathrm{Bb}$ & $5.94 \mathrm{Ab}$ \\
\hline $15-20$ & $28.07 \mathrm{BCC}$ & $32.22 \mathrm{Ac}$ & $24.98 \mathrm{Cc}$ & $31.62 \mathrm{Aba}$ & $5.33 \mathrm{ABcd}$ & $9.72 \mathrm{Ad}$ & $8.3 \mathrm{Ac}$ & $3.46 \mathrm{Bb}$ \\
\hline $20-25$ & $28.50 \mathrm{BCC}$ & $31.03 \mathrm{Abc}$ & $26.02 \mathrm{Cc}$ & $32.94 \mathrm{Aa}$ & 3.09 Bd & $6.68 \mathrm{ABd}$ & $8.8 \mathrm{Ac}$ & $3.67 \mathrm{Bb}$ \\
\hline CV (\%) & \multicolumn{4}{|c|}{5.52} & \multicolumn{4}{|c|}{12.13} \\
\hline Layer & \multicolumn{4}{|c|}{$\mathrm{OC}$} & \multicolumn{4}{|c|}{$\mathrm{H}+\mathrm{Al}^{+3}$} \\
\hline $\mathrm{cm}$ & \multicolumn{4}{|c|}{$\mathrm{g} \mathrm{kg}^{-1}$} & \multicolumn{4}{|c|}{$-\mathrm{cmol}_{\mathrm{c}} \mathrm{dm}^{-3}$} \\
\hline $0-5$ & $17.3 \mathrm{Ba}$ & $21.97 \mathrm{Aa}$ & $32.94 \mathrm{Aa}$ & $34.47 \mathrm{Aa}$ & $5.04 \mathrm{Aa}$ & 4.74 Aab & $4.67 \mathrm{Aa}$ & 3.3 Ba \\
\hline $5-10$ & 14.76 Bab & 17.71 ABab & $12.66 \mathrm{Bb}$ & $22.15 \mathrm{Ab}$ & 4.51 Aab & $4.46 \mathrm{Abc}$ & $3.55 \mathrm{Ab}$ & $3.54 \mathrm{Aa}$ \\
\hline $10-15$ & 12.19 Bab & $14.32 \mathrm{Bbc}$ & $13.76 \mathrm{Bb}$ & $15.38 \mathrm{BC}$ & 4.13 Bab & $5.65 \mathrm{Aa}$ & $3.36 \mathrm{Bb}$ & 3.43 Ba \\
\hline $15-20$ & 11.84 Aab & $11.02 \mathrm{Abc}$ & $9.35 \mathrm{Ab}$ & $12.67 \mathrm{Ac}$ & $3.81 \mathrm{Ab}$ & $4.16 \mathrm{Abc}$ & $3.29 \mathrm{Ab}$ & 3.32 Aa \\
\hline $20-25$ & $10.16 \mathrm{Ab}$ & $10.52 \mathrm{Ac}$ & $9.9 \mathrm{Ab}$ & $11.78 \mathrm{Ac}$ & $3.91 \mathrm{Ab}$ & $3.55 \mathrm{Ac}$ & $3.64 \mathrm{Aab}$ & $3.21 \mathrm{Aa}$ \\
\hline CV (\%) & \multicolumn{4}{|c|}{18.29} & \multicolumn{4}{|c|}{11.31} \\
\hline
\end{tabular}

organic components/molecules in the soil profile, i.e., up to $30 \mathrm{~cm}$ (Brunetto et al., 2012) or $60 \mathrm{~cm}$ (Lourenzi et al., 2011). Therefore, the application of LSM and other animal wastes becomes an important alternative for increasing soil organic $\mathrm{C}$ stocks both locally and globally (Maillard and Angers, 2014). Potential acidity $(\mathrm{H}+\mathrm{Al})$ was higher in the areas with LSM application in the $0-5 \mathrm{~cm}$ layer compared to the native forest, while in the $10-15 \mathrm{~cm}$ layer only the area with LSM application for eight years was different from the others (Figure 2B and Table 2). These results differ from those of Lourenzi et al. (2011) and Brunetto et al. (2012), which reported no change in potential acidity after successive LSM applications. Increments in potential acidity observed in this study are likely associated with increases in soil organic $\mathrm{C}$ (Figure 2A, Table $2)$, which present carboxylic and phenolic groups in humic and fulvic acids from the organic compounds of LSM (Lourenzi et al., 2011; Brunetto et al., 2012). Considering that negative electric charges present in tropical soils are directly associated with soil organic matter, organic $\mathrm{C}$ in- crements verified from the use of LSM are important for the retention of nutrients and pollutants in the soil.

The values of $\mathrm{pH}$ and base saturation had no significant interaction between the areas and the layers; thus, a simple effect of LSM application was shown in Figures $3 \mathrm{~A}$ and $3 \mathrm{~B}$. Higher $\mathrm{pH}$ values (Figure $3 \mathrm{~A}$ ) and base saturation percentages (Figure $3 \mathrm{~B}$ ) were observed in the area with 15 years of LSM application, which presented no differences from native forest (Figure 3A). In the long term, successive LSM applications attenuated soil acidity (Lourenzi et al., 2011), as well as increasing the base saturation of the soil (Oliveira et al., 2017) due to alkaline properties and dissociation of carbonates present in LSM (Chantigny et al., 2004). The reduction in active acidity can also be related to increases in soil organic C (Brunetto et al., 2012; Lourenzi et al., 2011), since it stimulates the adsorption of $\mathrm{H}^{+}$in the functional groups of the organic molecules, converging with higher $\mathrm{pH}$ values found in the areas with a greater amount of soil organic $\mathrm{C}$ in the surface layer (Figure 2A). 

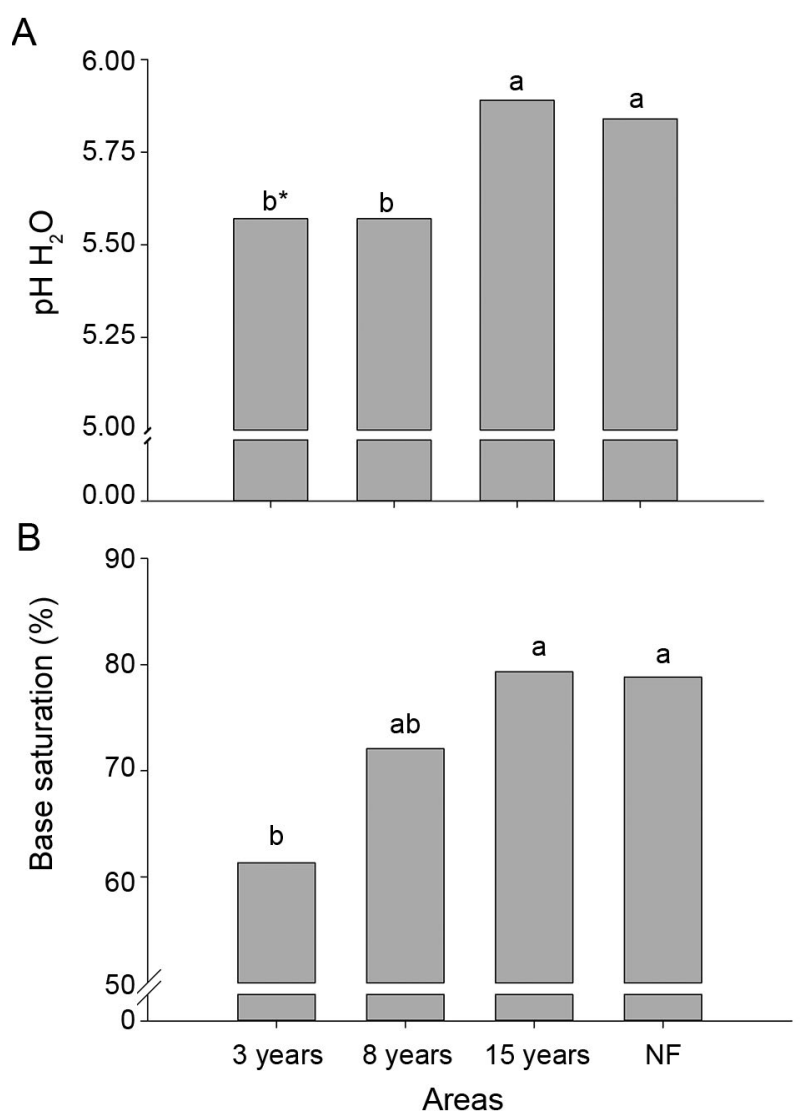

Figure 3 - Soil active acidity $\left(\mathrm{pH}\right.$ in $\left.\mathrm{H}_{2} \mathrm{O}\right)(\mathrm{A})$ and base saturation (B) in the native forest (NF) and areas under three, eight and 15 years of Cynodon cultivation with annual application of liquid swine manure (mean of layer $0-25 \mathrm{~cm}$ ). * Means followed by the same letter do not differ from each other according to Tukey's test $(p<0.05)$.

\section{Soil nutrient availability}

The application of LSM promoted an increase in available soil $\mathrm{P}$ contents in pasture areas, compared to native forest (Figure 4A and Table 2). These increases were most noticeable down to the $10-15 \mathrm{~cm}$ layer, reaching 100, 270 and $250 \mathrm{mg} \mathrm{dm}^{-3}$ in areas under three, eight and 15 years with the use of LSM in the $0-5 \mathrm{~cm}$ layer, while in the native forest soil $\mathrm{P}$ content was $6.1 \mathrm{mg}$ $\mathrm{dm}^{-3}$. In deeper layers (15-20 and 20-25 cm), available P contents were lower than $45 \mathrm{mg} \mathrm{dm}^{-3}$ in all areas.

In tropical soils, the great majority of soil $\mathrm{P}$ is adsorbed in $\mathrm{Fe}$ and $\mathrm{Al}$ oxides through the ligand exchange mechanism with high energy, a unidirectional process that makes $\mathrm{P}$ unavailable to plants (Guardini et al., 2012; Cherubin et al., 2016; Rodrigues et al., 2017). Therefore, $\mathrm{P}$ is immobile in the soil profile, which explains its high concentration in the shallowest layers with successive additions of LSM, as has also been reported in the literature (Ceretta et al., 2010; Lourenzi et al., 2015; Oliveira et al., 2017; Boitt et al., 2018). However, excessive increments of $\mathrm{P}$ in soil solution associated with presence of organic acids may saturate surface functional groups in the topsoil, which may increase $\mathrm{P}$ vertical migration (Pavinato and Rosolem, 2008; Fink et al., 2016).

Studies have shown that the concentration of $\mathrm{P}$ in the surface layers is higher with the application of LSM, increasing down to the $20-25 \mathrm{~cm}$ layer (Ceretta et al., 2010; Boitt et al., 2018). The increase of $\mathrm{P}$ at depth with the application of manure occurs mainly in inorganic form (Koopmans et al., 2007; Ojekanmi et al., 2011), without affecting the partition between inorganic and organic forms after seven years of application of LSM (Ceretta et al., 2010). In addition, about $48 \%$ of the $\mathrm{P}$ in LSM is found in water-soluble form (Li et al., 2014). Thus, the successive application of LSM increases the amount of $\mathrm{P}$ in the labile forms in the soil solution /Ceretta et al., 2010), which are susceptible to movement and loss with the percolation water. Boitt et al. (2018) point out that $58-83 \%$ of the $\mathrm{P}$ added through 15 years of LSM application remained in the soil, whereas 6 to $38 \%$ was not recovered, possibly being lost by leaching.

The concentration of $\mathrm{P}$ in the soil reached values of $250 \mathrm{mg} \mathrm{kg}^{-1}$, and was classified as "very high" according to soil fertility standards for suitable crop nutrition (CQFS-RS/SC, 2016). Thus, the amount of $\mathrm{P}$ above the crop requirement corresponds to overfertilization and may exceed the critical environmental limit of the soil nutrient (Gatiboni et al., 2015), thereby increasing the risk of movement of this contaminant, especially through surface runoff (Lourenzi et al., 2015) to water bodies, and becoming an important source of environmental pollution (Gatiboni et al., 2015). A study conducted by Lourenzi et al. (2015) revealed that the main forms of $\mathrm{P}$ carried by runoff were available $\mathrm{P}$, soluble $\mathrm{P}$ and particulate $\mathrm{P}$. Therefore, monitoring soil $\mathrm{P}$ levels in areas under successive LSM applications should be carried out periodically, so that excessive increase of $\mathrm{P}$ levels under pasture can be carefully evaluated (Oliveira et al., 2017). These precautions are even more important in undulating landscapes, which are typical in swine farms in southern Brazil, since they intensify the risks of $P$ transfer via runoff to watercourses close to the areas of LSM application.

The use of LSM for eight and 15 years promoted an increase in $\mathrm{K}$ content in soil relative to areas with three years of LSM application or native forest (Figure $4 \mathrm{~B}$ and Table 2), even under forage cultivation with a large amount of $\mathrm{K}$ (Brink et al., 2003). In the 15 years of LSM-amended area, the $\mathrm{K}$ content was higher in the 0-5, 5-10 and 10-15 cm layers, while in the eight-year area the highest levels were found in the 15-20 and 20$25 \mathrm{~cm}$ layers. Despite being numerically higher, soil K content in the three-year area of LSM application did not significantly differ from the native forest, except for the 15-20 cm layer, where $\mathrm{K}$ levels are higher in the LSMamended areas (Figure 4B and Table 2).

$\mathrm{K}$ presents lower retention in soil colloids in comparison to $\mathrm{Ca}$ and $\mathrm{Mg}$, due to its monovalence and greater hydration radius, making it more mobile in the 
soil. This explains the increase in $\mathrm{K}$ with greater depth following successive applications of LSM (Lourenzi et al., 2013; Grohskopf et al., 2016a; Oliveira et al., 2017). However, increases in negative charges in the soil induced by higher organic $\mathrm{C}$ content and $\mathrm{pH}$ values in the surface layer may also reduce $\mathrm{K}$ translocation to deeper soil layers (Ernani et al., 2012), as observed for the area fertilised for 15 years compared to the area fertilised for eight years (Figure 4B and Table 2). Increases in soil K induced by LSM application agree with results reported by Oliveira et al. (2017), which verified that K levels in pasture areas fertilised with LSM over 15 years were 2 , 3 and even 4 times higher in the 0-10, 10-20 and 20-40 $\mathrm{cm}$ layers respectively, compared to those quantified in the native forest. As discussed for $\mathrm{P}$, the excess of $\mathrm{K}$ in soil can also become a problem, due to the imbalance in relationships with other cations, such as $\mathrm{Ca}$ and $\mathrm{Mg}$ in the exchange complex.
The $\mathrm{Ca}$ and $\mathrm{Mg}$ contents of the soil were also increased by the application of LSM (Figure 4C and D, Table 2), although the absolute increases were less than those observed for P and K. Despite this, 15 years of LSM application were not enough to increase Ca content in the surface layer $(0-5 \mathrm{~cm})$ to levels similar to those verified in native forest (Figure 4C and Table 2). However, in the deeper layers, Ca content did not differ between areas under 15 years of LSM application and native forest. The use of LSM promoted gradual increases in Mg content over time; however, regardless of the LSM application time, the values remained lower than those observed in native forest soil. In sandy soil (17\% of clay), Lourenzi et al. (2011) observed increases in $\mathrm{Ca}$ and $\mathrm{Mg}$ down to a depth of $20 \mathrm{~cm}$ after 19 applications of LSM. In very clayey soil, Oliveira et al. (2017) found increases down to a depth of $40 \mathrm{~cm}$ under pasture with more than 15 years of LSM applications. Thus, cation movement in

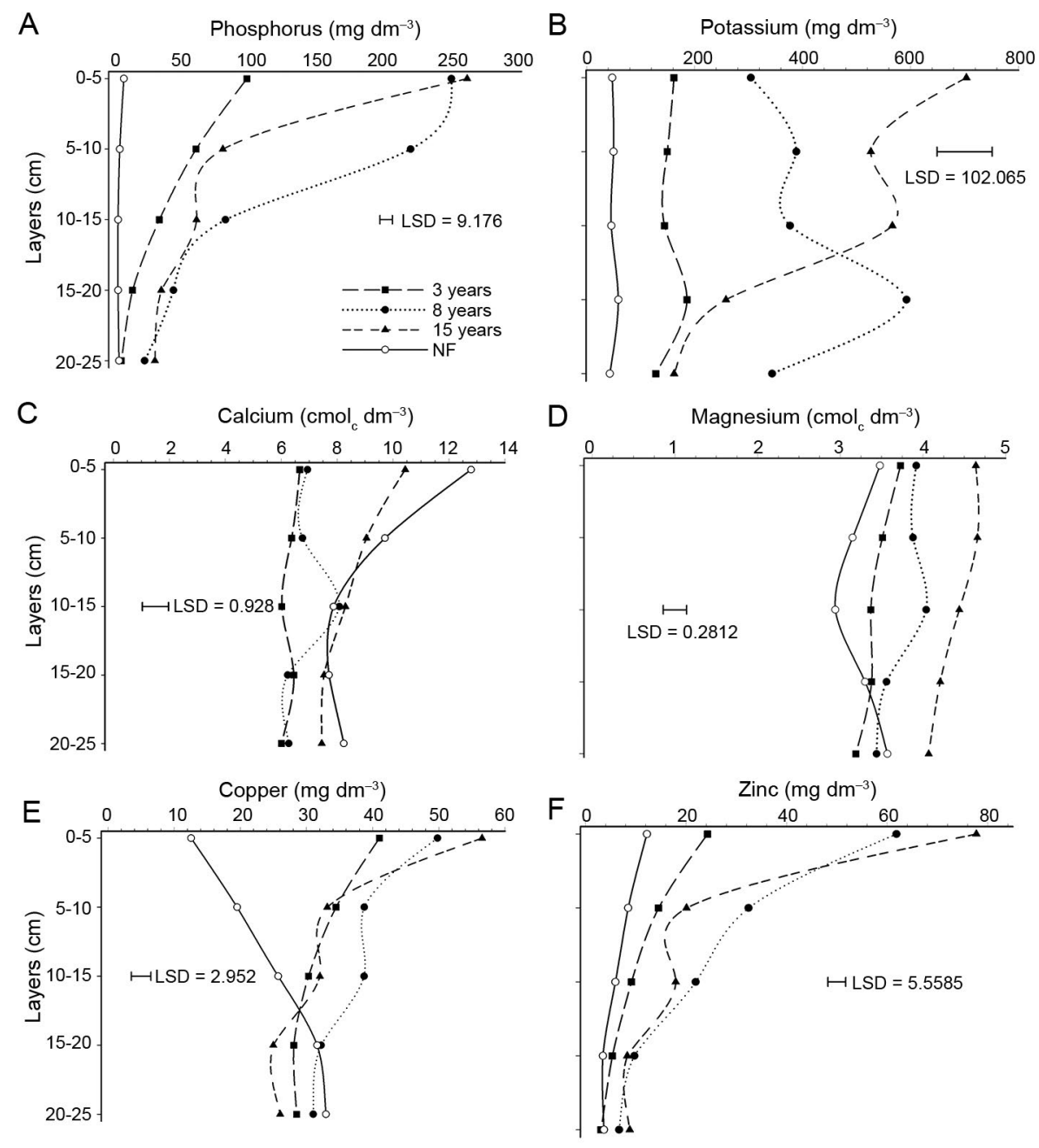

Figure 4 - Soil available phosphorus (A), potassium (B), calcium (C), magnesium (D), copper (E) and zinc (F) content in the native forest (NF) and areas under three, eight and 15 years of Cynodon cultivation with annual application of liquid swine manure. Horizontal line indicates the least significant difference (LSD) according to Tukey's test $(p<0.05)$. 
sandy soils is explained by the LSM load and the length of time management has had this strategy in force.

With regard to to the $\mathrm{Cu}$ and $\mathrm{Zn}$ concentrations, soils under pasture with successive applications of LSM showed high concentrations of these micronutrients, up to six and four times higher than the native forest in the surface layers (Figure 4E and $\mathrm{F}$ and Table 2) - the longer the use time of LSM, the higher the nutrient content in the soil. The concentrations reduced with depth, and from the 15-20 cm layer there were no measurable differences between soils under pasture or native forest. The LSM had high concentrations of $\mathrm{Cu}$ and $\mathrm{Zn}$ as they were supplemented via swine feed and later excreted in the feces ( $\mathrm{Li}$ et al., 2007). These elements have little mobility in the soil, therefore, successive LSM applications have been associated with accumulations in the surface layers (Formentini et al., 2015; De Conti et al., 2016; Oliveira et al., 2017). Cu has a high affinity for forming stable complexes with functional groups of soil organic matter (De Conti et al., 2016), while $\mathrm{Zn}$ is primarily adsorbed on surface functional groupings of mineral particles, such as iron oxides (Grohskopf et al., $2016 b)$. Furthermore, the pH of soil solution affects the solubility of both elements (De Conti et al., 2016).

The soil contents of $\mathrm{Cu}>0.4$ and $\mathrm{Zn}>0.5 \mathrm{mg}$ $\mathrm{dm}^{-3}$ are classified as "very high" in terms of plant nutrition (CQFS-RS/SC, 2016), and it was observed that the natural background is also rich in these elements. For example, the native forest soil content of these elements is very high. A high level of $\mathrm{Cu}$ and $\mathrm{Zn}$ can be associated with an abundance of these elements in the basalt, which is the parental material of the soils in the area studied (Formentini et al., 2015). However, when using LSM these levels increased significantly, raising concerns about soil contamination, as well as the transfer of these elements to the watercourses nearby (Formentini et al., 2015; Broetto et al., 2014; Pereira et al., 2016; De Conti et al., 2016; Oliveira et al., 2017).
Therefore, the monitoring of these areas of continuous use of LSM is fundamental to properly planned LSM application (i.e., reducing the applied volume or even ceasing the application) in a way that avoids problems related to contamination of heavy metals in pasture areas as well as its transfer within the trophic chain of the production system.

\section{Impacts of LSM applications on soil physical attributes}

Soil bulk density was significantly higher in the area with three years of LSM, decreasing with increasing time of use of LSM, especially in the shallower layer $(2-7 \mathrm{~cm})$ (Table 3). In the deeper layers, soils under pasture, regardless of the time of LSM use, presented $\rho_{b}$ values higher than the native forest soil. Variations in $\rho_{b}$ caused by the soil management directly affected pore distribution in the soil. Thus, higher $\rho_{\mathrm{b}}$ values were associated with a reduction in porous space in the soil, especially in relation to macroporosity (Table 3), which was lower by $10 \%$ in the pasture areas, indicating potential restriction of the diffusion of oxygen in the soil and, consequently, to plant growth. The highest $\rho_{b}$ in the area with three years of LSM application may be an effect of animal trampling (Ambus et al., 2018) and associated soil compaction from soil tillage and machine traffic. In this situation, the use of LSM for three years seems not to have been enough to provide improvements in the structural quality of the soil, not even in the surface layer. Cherubin et al. (2015) also showed that the application of up to $80 \mathrm{~m}^{3} \mathrm{ha}^{-1} \mathrm{yr}^{-1}$ of LSM in notillage areas did not reduce $\rho_{b}$ to levels similar to native forest. However, results reported by Freitas et al. (2018), where the application of LSM up to a dosage of $480 \mathrm{~m}^{3}$ $\mathrm{ha}^{-1} \mathrm{yr}^{-1}$, for four years in perennial pasture, reduced $\rho_{\mathrm{b}}$ in the superficial layer.

In the eight and 15 year areas, the time elapsed after planting the pasture and the action of the Cynodon

Table 3 - Soil bulk density $\left(\rho_{\mathrm{b}}\right)$, total porosity, macroporosity and microporosity in the native forest (NF) and areas under three, eight and 15 years of Cynodon cultivation with annual application of liquid swine manure.

\begin{tabular}{|c|c|c|c|c|c|c|c|c|}
\hline & 3 years & 8 years & 15 years & NF & 3 years & 8 years & 15 years & $\mathrm{NF}$ \\
\hline Layer & \multicolumn{4}{|c|}{$\rho_{b}$} & \multicolumn{4}{|c|}{ Total porosity } \\
\hline $\mathrm{cm}$ & \multicolumn{4}{|c|}{$-\mathrm{kg} \mathrm{dm}^{-3}$} & & 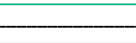 & 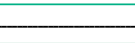 & \\
\hline $2-7$ & $1.47 \mathrm{Aa}^{*}$ & 1.32 Ba & $1.23 \mathrm{Bb}$ & $1.18 \mathrm{Ba}$ & $49.81 \mathrm{Ca}$ & 55.83 Bab & $57.36 \mathrm{ABa}$ & $60.32 \mathrm{Aa}$ \\
\hline $5-10$ & $1.41 \mathrm{Aa}$ & $1.43 \mathrm{Aa}$ & $1.37 \mathrm{Aa}$ & $1.21 \mathrm{Ba}$ & $51.88 \mathrm{Ba}$ & $51.19 \mathrm{BC}$ & $50.71 \mathrm{Bb}$ & $59.23 \mathrm{Aa}$ \\
\hline $10-15$ & $1.42 \mathrm{Aa}$ & $1.39 \mathrm{Aa}$ & $1.40 \mathrm{Aa}$ & 1.14 Ba & $52.20 \mathrm{Ba}$ & $52.03 \mathrm{Bbc}$ & $49.79 \mathrm{Bb}$ & $60.36 \mathrm{Aa}$ \\
\hline $15-20$ & $1.38 \mathrm{Aa}$ & $1.33 \mathrm{Aa}$ & $1.38 \mathrm{Aa}$ & 1.14 Ba & $53.09 \mathrm{BCa}$ & $56.42 \mathrm{Ba}$ & $50.14 \mathrm{Cb}$ & $61.08 \mathrm{Aa}$ \\
\hline $\mathrm{CV}(\%)$ & \multicolumn{4}{|c|}{6.92} & \multicolumn{4}{|c|}{4.62} \\
\hline Layer & \multicolumn{4}{|c|}{ Macroporosity } & \multicolumn{4}{|c|}{ Microporosity } \\
\hline $\mathrm{cm}$ & & & & & & & & \\
\hline $2-7$ & $5.06 \mathrm{Ba}$ & $9.53 \mathrm{ABab}$ & $8.61 \mathrm{ABa}$ & $12.68 \mathrm{Ab}$ & $44.75 \mathrm{Aa}$ & $46.30 \mathrm{Aa}$ & $48.75 \mathrm{Aa}$ & $47.64 \mathrm{Aa}$ \\
\hline $5-10$ & $7.60 \mathrm{Ba}$ & $7.97 \mathrm{Bb}$ & $7.20 \mathrm{Ba}$ & 16.96Aab & $44.27 \mathrm{Aa}$ & $43.23 \mathrm{Aa}$ & $43.51 \mathrm{Ab}$ & $42.28 \mathrm{Ab}$ \\
\hline $10-15$ & $6.14 \mathrm{Ba}$ & $7.35 \mathrm{Bb}$ & $6.14 \mathrm{Ba}$ & $21.03 \mathrm{Aa}$ & 45.39 Aa & $44.68 \mathrm{Aa}$ & $43.65 \mathrm{Ab}$ & $39.34 \mathrm{Bb}$ \\
\hline $15-20$ & $7.16 \mathrm{Ba}$ & $13.30 \mathrm{Aa}$ & $7.16 \mathrm{Ba}$ & $19.07 \mathrm{Aa}$ & $46.02 \mathrm{Aa}$ & $43.12 \mathrm{Aa}$ & $42.98 \mathrm{Ab}$ & $42.01 \mathrm{Ab}$ \\
\hline CV (\%) & \multicolumn{4}{|c|}{33.92} & \multicolumn{4}{|c|}{5.66} \\
\hline
\end{tabular}




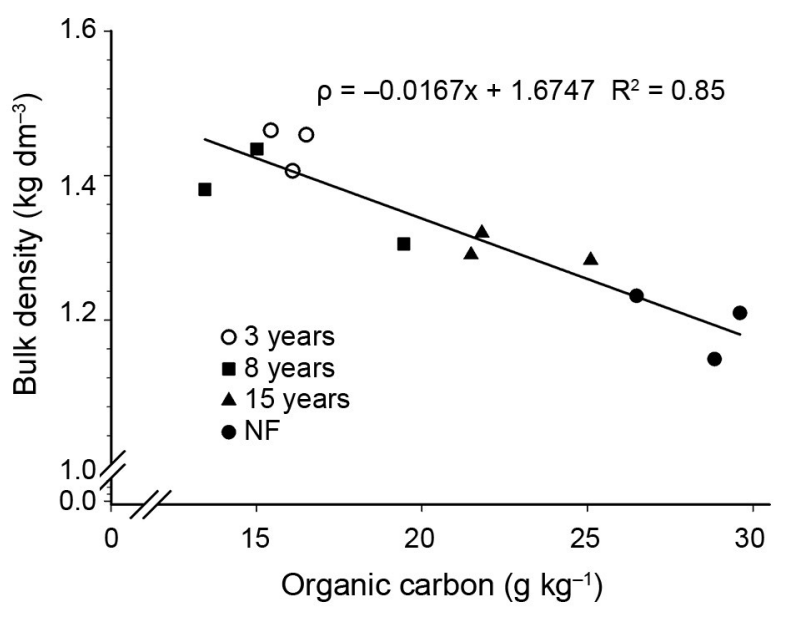

Figure 5 - Relationship between soil density and organic $C$ in native forest (NF) and areas under three, eight and 15 years of Cynodon cultivation with application of liquid swine manure.

root system probably led to a better restructuring of the surface soil layer. In addition, prolonged use of LSM allowed for $\mathrm{C}$ increases in the surface layers (Figure 2A), which favors the formation of organomineral complexes (Six et al., 2004) and biological activity, which positively affect the process of soil aggregation (Lehmann et al., 2017). Consequently the structural quality of the soil showed that an increase in $\mathrm{C}$ was positively associated with the reduction in $\rho_{b}$ (Figure 5). However, taking into consideration the high values of $\rho_{b}$ and reduced macroporosity, and values observed in the pasture areas (Table 3), these benefits to the soil structure provided by the successive use of LSM are still very limited and are insufficient to fully alleviate limiting conditions induced by soil compaction to ensure suitable root growth (Moraes et al., 2018).

\section{Conclusions}

Successive applications of LSM $\left(200 \mathrm{~m}^{3} \mathrm{ha}^{-1} \mathrm{yr}^{-1}\right)$ in the Cynodon spp. pasture areas reduces active acidity and increases the organic $\mathrm{C}$ content and plant-available nutrient $(\mathrm{P}, \mathrm{K}, \mathrm{Ca}, \mathrm{Mg}, \mathrm{Cu}$ and $\mathrm{Zn})$ contents in the soil. However, most of these effects were only significant in the surface layers $(0-10 \mathrm{~cm})$ and increased according to the duration of application of LSM in the area (15 > eight $>$ three years). Despite the benefits promoted by the use of LSM to soil chemical quality, excessive increases in $\mathrm{P}, \mathrm{Cu}$ and $\mathrm{Zn}$ should be monitored to minimize the risks of soil pollution as well as surface and groundwater contamination.

Changes in soil physical attributes were more related to the land use (pasture versus native forest) than to the duration of application of LSM. Soil physical quality was slightly enhanced by the long-term use of LSM (15 years), with small reductions in $\rho_{b}$ and increases in porosity of the soil surface layer. Therefore, the effect of LSM in the period evaluated is not enough to significantly attenuate the physical degradation of the soil imposed by continuous animal grazing in Cynodon pasture areas.

\section{Authors' Contributions}

Conceptualization: Scheid, D.L.; Silva, R.F.; Da Ros, C.O.; Rodrigues, V.R. Data acquisition: Scheid, D.L.; Pinto, M.A.B.; Gabriel, M. Data analysis: Scheid, D.L.; Cherubin, M.R. Design of methodology: Scheid, D.L.; Silva, R.F.; Da Ros, C.O.; Rodrigues, V.R. Writing and editing: Scheid, D.L.; Cherubin, M.R.; Silva, R.F.; Da Ros, C.O.; Rodrigues, V.R.; Pinto, M.A.B.; Gabriel, M.

\section{References}

Alvares, C.A.; Stape, J.L.; Sentelhas, P.C.; Gonçalves, J.L.M.; Sparovek, G. 2014. Köppen's climate classification map for Brazil. Meteorologische Zeitschrift 22: 711-728.

Ambus, J.V.; Reichert, J.M.; Gubiani, P.G.; Carvalho, P.C.F. 2018. Changes in composition and functional soil properties in longterm no-till integrated crop-livestock system. Geoderma 330: 232-243.

Ames, J.P.; Neres, M.A.; Castagnara, D.D.; Mufatto, L.M.; Jobim, C.C.; Tres, T.T. 2014. Dry matter production, chemical composition, dry matter digestibility and occurrence of fungi in Bermuda grass hay (Cynodon dactylon) under different fertilization systems or associated with pea plantings in winter. Ciencia e Investigación Agraria 41: 163-174.

Boitt, G.; Schmitt, D.E.; Gatiboni, L.C.; Wakelin, S.A.; Black, A.; Sacomori, W.; Cassol, P.C.; Condron, L.M. 2018. Fate of phosphorus applied to soil in pig slurry under cropping in southern Brazil. Geoderma 321: 164-172.

Bonetti, J.A.; Anghinoni, I.; Moraes, M.T.; Fink, J.R. 2017. Resilience of soils with different texture, mineralogy and organic matter under long-term conservation systems. Soil Tillage Research. 174: 104-112.

Brink, G.E.; Rowe, D.E.; Sistani, K.R.; Adeli, A. 2003. Bermudagrass cultivar response to swine effluent application. Agronomy Journal 95: 597-601.

Broetto, T.; Tornquist, C.G.; Bayer C.; Campos, B.C.; Merten, C.G.; Wottrich, B. 2014. Soils and surface waters as affected by long-term swine slurry application in oxisols of southern Brazil. Pedosphere 24: 585-594.

Brunetto, G.; Comin, J.J.; Schmitt, D.E.; Guardini, R.; Mezzari, C.P.; Oliveira, B.S.; Moraes, M.P.; Gatiboni, L.C.; Lovato, P.E.; Ceretta, C.A. 2012. Changes in soil acidity and organic carbon in a sandy typic hapludalf after medium-term pig-slurry and deep-litter application. Revista Brasileira de Ciência do Solo 36: 1620-1628.

Burton, G.W. 2001. Tifton bermudagrass: early history of its creation, selection, and evaluation. Crop Science 41: 5-6.

Ceretta, C.A.; Lorensini, F.; Brunetto, G.; Girotto, E.; Gatiboni, L.C.; Lourenzi, C.R.; Tiecher, T.L.; De Conti, L.; Trentin, G.; Miotto, A. 2010. Phosphorus fractions in soil after successive pig slurry applications in no-tillage system. Pesquisa Agropecuára Brasileira 45: 593-602 (in Portuguese, with abstract in English). 
Chantigny, M.H.; Rochette, P.; Angers, D.A.; Masseé, D.; Côte, D. 2004. Ammonia volatilization and selected soil characteristics following application of anaerobically digested pig slurry. Soil Science Society of America Journal 68: 306-312.

Cherubin, M.R.; Eitelwein, M.T.; Fabbris, C.; Weirich, S.W.; Silva, R F.; Silva, V.R.; Basso, C.J. 2015. Physical, chemical, and biological quality in an oxisol under different tillage and fertilizer sources. Revista Brasileira de Ciência do Solo 39: 615625 (in Portuguese, with abstract in English).

Cherubin, M.R.; Franco, A.L.C.; Cerri, C.E.P.; Karlen, D.L.; Pavinato, P.S.; Rodrigues, M.; Davies, C.A.; Cerri, C.C. 2016. Phosphorus pools responses to land-use change for sugarcane expansion in weathered Brazilian soils. Geoderma 265: 27-38.

Comissão de Química e Fertilidade do Solo do Rio Grande do Sul e Santa Catarina [CQFS-RS/SC]. 2016. Manual of Liming and Fertilization for the states of Rio Grande do Sul and Santa Catarina = Manual de Calagem e Adubação para os Estados do Rio Grande do Sul e Santa Catarina. 11ed. Sociedade Brasileira de Ciência do Solo, Santa Maria, RS, Brazil (in Portuguese).

De Conti, L.; Cerreta, C.A.; Ferreira P.A.A.; Lourenzi, C.R.; Girotto, E.; Lourensini, F.; Tiecher, T.L.; Marchezen, C.; Anchieta, M.G.; Brunetto, G. 2016. Soil solution concentrations and chemical species of copper and zinc in a soil with a history of pig slurry application and plant cultivation. Agriculture, Ecosystems and Environment 216: 374-386.

Drewry, J.J.; Cameron, K.C.; Buchan, G.D. 2008. Pasture yield and soil physical property responses to soil compaction from treading and grazing: a review. Australian Journal of Soil Research 46: 237-256.

Ernani, P.R.; Mantovani, A.; Scheidt, F.R.; Nesi, C. 2012. Liming decreases the vertical mobility of potassium in acidic soils. Communications in Soil Science and Plant Analysis 43: 25442549.

Food and Agriculture Organization [FAO]. 2019. FAOSTAT: food and agriculture data; livestock primary. Available at: www.fao. org/faostat/en/\#home [Accessed Jan 23, 2019]

Fink, J.R.; Inda, A.V.; Bavaresco, J.; Barrón, V.; Torrent, J.; Bayer, C. 2016. Adsorption and desorption of phosphorus in subtropical soils as affected by management system and mineralogy. Soil Tillage Research 155: 62-68.

Formentini, T.A.; Mallmann, F.J.K.; Pinheiro, A.; Fernandes, C.V.S.; Bender, M.A. Veiga, M.; Santos, D.R.; Doelsch, E. 2015. Copper and zinc accumulation and fractionation in a clayey Hapludox soil subject to long-term pig slurry application. Science of the Total Environment 536: 831-839.

Freitas, J.A.S.; Silva, V.R.; Luz, F.B.; Kaiser, D.R.; Zwirtes, A.L. 2018. Soil carbon and physical-mechanical properties after successive applications of swine and poultry organic waste. Pesquisa Agropecuária Tropical 48: 390-398.

Gatiboni, L.C.; Smyth, T.J.; Schmitt, D.E.; Cassol, P.C.; Oliveira, C.M.B. 2015. Soil phosphorus thresholds in evaluating risk of environmental transfer to surface waters in Santa Catarina, Brazil. Revista Brasileira de Ciência do Solo 39: 1225-1234.

Grohskopf, M.A.; Cassol, P.C.; Corrêa, J.C.; Albuquerque, J.A.; Ernani, P.R.; Mafra, M.S.H.; Mafra, A.L. 2016a. Soil solution nutrient availability, nutritional status and yield of corn grown in a typic Hapludox under 12 years of pig slurry fertilizations. Revista Brasileira de Ciência do Solo 40: e0150341.
Grohskopf, M.A.; Correa, J.C.; Cassol, P.C.; Nicoloso, R.S.; Fernandes, D.M. 2016b. Copper and zinc forms in soil fertilized with pig slurry in the bean crop. Revista Brasileira de Engenharia Agrícola e Ambiental 20: 823-829.

Guardini, R.; Comin, J.J.; Santos, D.R.; Gatiboni, L.C.; Tiecher, T.; Schmitt, D.; Bender, M.A.; Belli, P.; Oliveira, P.A.V.; Brunetto, G. 2012. Phosphorus accumulation and pollution potential in a Hapludult fertilized with pig manure. Revista Brasileira de Ciência do Solo 36: 1333-1342.

Johannes, A.; Matter, A.; Schulin, R.; Weisskopf, P.; Baveye, P.C.; Boivin, P. 2017. Optimal organic carbon values for soil structure quality of arable soils. Does clay content matter? Geoderma 302: 14-21.

Koopmans, G.F.; Chardon, W.J.; McDowell, R.W. 2007. Phosphorus movement and speciation in a sandy soil profile after long-term animal manure applications. Journal of Environmental Quality 36: 305-315.

Lehmann, A.; Zheng, W.; Rilling, M.C. 2017. Soil biota contributions to soil aggregation. Nature Ecology \& Evolution 1: $1828-1835$

Li, G.; Li, H.; Leffelaar, P.A.; Shen, J.; Zhang, F. 2014. Characterization of phosphorus in animal manures collected from three (dairy, swine, and broiler) farms in China. Plos One 9: e102698.

Li, Y.X.; Li, W.; Wu, J.; Xu, L.C.; Su, Q.H.; Xiong, X. 2007. Contribution of additives $\mathrm{Cu}$ to its accumulation in pig feces: study in Beijing and Fuxin of China. Journal of Environmental Sciences 19: 610-615.

Lourenzi, C.R.; Ceretta, C.A.; Silva, L.S.; Girotto, E.; Lorensini, F.; Tiecher, T.L.; De Conti, L.; Trentin, G.; Brunetto, G. 2013. Nutrients in soil layers under no-tillage after successive pig slurry applications. Revista Brasileira de Ciência do Solo 37: 157-167.

Lourenzi, C.R.; Ceretta, C.A.; Silva, L.S.; Trentin, G.; Girotto, E.; Lorensini, F; Tiecher, T.L.; Brunetto, G. 2011. Soil chemical properties related to acidity under successive pig slurry application. Revista Brasileira de Ciência do Solo 35: 18271836.

Lourenzi, C.R.; Ceretta, C.A.; Tiecher, T.L.; Lorensini, F.; Cancian, A.; Stefanello, L.; Girotto, E.; Vieira, R.C.B.; Ferreira, P.A.A.; Brunetto, G. 2015. Forms of phosphorus transfer in runoff under no-tillage in a soil treated with successive swine effluents applications. Environmental Monitoring and Assessment 187: 209.

Mafra, M.S.H.; Cassol, P.C.; Albuquerque, J.A.; Grohskopf, M.A.; Andrade, A.P.; Rauber, L.P.; Friederichs, A. 2015. Organic carbon contents and stocks in particle size fractions of a typic Hapludox fertilized with pig slurry and soluble fertilizer. Revista Brasileira de Ciência do Solo 39: 11611171.

Maillard, É.; Angers, D.A. 2014. Animal manure application and soil organic carbon stocks: a meta-analysis. Global Change Biology 20: 666-679.

Moraes, M.T.; Bengough, A.G.; Debiasi, H.; Franchini, J.C.; Levien, R.; Schnepf, A.; Leitner, D. 2018. Mechanistic framework to link root growth models with weather and soil physical properties, including example applications to soybean growth in Brazil. Plant and Soil 428: 67-92. 
Ojekanmi, A.; Ige, D.; Hao, X.; Akinremi, O. 2011. Phosphorus mobility in a soil with long term manure application. Journal of Agricultural Science 3: 25-38.

Oliveira, D.M.S.; Lima, R.P.; Barreto, M.S.C.; Verburg, E.E.J.; Mayrink, G.C.V. 2017. Soil organic matter and nutrient accumulation in areas under intensive management and swine manure application. Journal of Soils and Sediments 17: 1-10. DOI 10.1007/s11368-016-1474-6

Pavinato, P.S.; Rosolem, C.A. 2008. Effects of organic compounds produced by plants on soil nutrient availability. Revista Brasileira de Ciência do Solo 32: 911-920 (in Portuguese, with abstract in English).

Pereira, P.A.M.; Sampaio, S.C.; Reis, R.R.; Rosa, D.M.; Correa, M.M. 2016. Swine farm wastewater and mineral fertilization in corn cultivation. Revista Brasileira de Engenharia Agrícola e Ambiental 20: 49-54.

Rodrigues, M.; Rabêlo, F.H.S.; Castro, H.A.; Roboredo, D.; Carvalho, M.A.C.; Roque, C.G. 2017. Changes in chemical properties by use and management of an Oxisol in the Amazon biome. Revista Caatinga 30: 278-286.
Schaefer, C.E.G.R.; Fabris, J.D.; Ker, J.C. 2008. Minerals in the clay fraction of Brazilian Latosols (Oxisols): a review. Clay Minerals 43: 137-154.

Six, J.; Bossuyt, H.; Degryze, S.; Denef, K. 2004. A history of research on the link between (micro) aggregates, soil biota, and soil organic matter dynamics. Soil Tillage Research 79: 7-31.

Soil Survey Staff. 2014. Keys to Soil Taxonomy, 12ed. USDANatural Resources Conservation Service, Washington, DC, USA.

Teixeira, P.C.; Donagemma, G.K.; Fontana, A.; Teixeira, W.G. 2017. Manual of Soil Analysis Methods = Manual de Métodos de Análises de Solo. Embrapa, Brasília, DF, Brazil (in Portuguese).

Woli, K.P.; Rakshit, S.; Lundvall, J.P.; Sawyer, J.E.; Barker, D.W. 2013. On-farm evaluation of liquid swine manure as a nitrogen source for corn production. Agronomy Journal 105: 248-262.

Yeomans, J.C.; Bremner, J.M. 1988. A rapid and precise method for routine determination of organic carbon in soil. Communications in Soil Science and Plant Analysis 19: 14671476 . 